\title{
Social Networking And Pedagogical Variations: An Integrated Approach For Effective Interpersonal And Group Communications Skills Development
}

\author{
Ephraim Okoro, Howard University, USA
}

\begin{abstract}
Electronic communication and social networking are effective and useful tools in the process of teaching and learning and have increasingly improved the quality of students' learning outcomes in higher education in recent years. The system encourages and supports students' active engagement, collaboration, and participation in class activities and provides a process of information dissemination in a unique method that yields measurable results. Faculty members are capable of monitoring and evaluating collaborative and independent efforts and activities of students and can provide immediate and timely feedback to students. While there are some issues and concerns regarding social networking and students' learning, numerous studies indicate that performance assessment and learning outcomes are adequately and objectively measured and managed as a result of social networking mechanism. Additionally, electronic media enhance collaborative learning activities and experiences. Effective and selective use of electronic and social networking tools in learning environments by innovative-minded and interactive faculty can sustain the quality of instructions and skills-development in communications disciplines.
\end{abstract}

Keywords: Social Networking; Facebook; Social Media; Business Communication; Teaching and Learning

\section{INTRODUCTION}

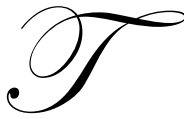

he advent of the electronic media and social networking systems has been a dominant trend in teaching and learning environments for over a decade. This technological concept has been fully developed and has continued to attract much scholarly attention in academic journals. Researchers across academic disciplines (Warren, 2010; Wandel, 2007; Santovec, 2006) emphasize that rapid development of communication processes, electronic media, and technological processes have improved the quality of teaching and learning in colleges and universities in recent years. Students learn much better, work independently and collaboratively, and acquire self discipline as a result of social networking and personal engagement (Zhao \& Kuh, 2004). Furthermore, faculty members perform at their level best, demonstrate outstanding pedagogical commitment in an engaged and collaborative learning environment, and they can better measure learning outcomes when students are participating actively (Hakane, Bakker, \& Schaufeli, 2006). In the past few years, electronic social networks have facilitated teaching and learning and have also increased the level of faculty and student enthusiasm and interests in the learning process and activities. Indeed, some studies (Magnoler \& Giannandrea, 2008; Suskie, 2004; Young, 2002) indicate a strong positive correlation between social networking and students' enduring dedication and interest in knowledge acquisition. It is, therefore, not surprising that social networking sites have increasingly sustained, enhanced, and improved the methodology of interactions in academic, social, and professional settings. Evidently, the discovery of these systems of communication (Facebook, LinkedIn, MySpace, Blackboard) have dramatically transformed the landscape of interpersonal and group communication and have, to a large extent, minimized the need for face-to-face meetings and discussions in teaching and learning. 
The impact of social networking on the learning process and outcomes is widespread. Selwyn (2009) acknowledges the mixed feelings with which the system has received since its inception, especially on students' learning outcomes. Selwyn determines that "Fears abound within some sections of the educational community that social networking sites could contribute to the intellectual and shcolarly de-powering of a 'Google Generation' of learners incapable of independent critical thought and generally hasten the onset of what Ziegler has termed the 'mis-education of Generation M' (p. 158)." Contrary to expressed doubts, recent studies strongly indicate that the use of social networking sites have been instrumental to an increase in academic performance and business productivity. Consistently, students, faculty, and business professionals agree that electronic media and social netowking sites have been conducive to learning and productive enggements among learners (Selwyn, 2009; Genova, 2009; Hathi, 2008). While Selwyn uncovers some specific features of social networking that impact existing instructional content and methodology, the operational sophistication associated with electronic media by far compensates for whatever deficiencies, inadequacies, and challenges are inherent in the system.

\section{Experience with Electronic Media and Social Networking Systems}

At a recent end-of-the-year faculty retreat, much emphasis was placed on teaching effectiveness, student learning outcomes, faculty teaching strategies and practices, and assurance of learning. These topics generated intense and prolonged discussions and debate among participants, and a number them were interested in the instructional quality issues, specifically assurance of students' learning and effective teaching techniques. Everyone felt the anxiety and urgent need about staying current in teaching techniques and ensuring students' learning outcomes. Based on these statements, motivation and interest in investigating and analyzing the potential benefits and drawbacks of using or integrating electronic media and social networking in business communication and related courses was developed.

The need to write this paper was further motivated partly by the interest to assess and establish an understanding of the role of electronic media and social networking in teaching and learning communication practices and strategies in business organizations, such as interpersonal and team skills, data collection and analysis, decision-making techniques, and computer and electronic media skills. Essentially, these are some of the basic skills needed in workplaces in domestic and global businesses. Students who have taken communication courses should be able to demonstrate this knowledge, abilities, and competencies. Other motivations for this paper were to determine whether or not social networking tools and electronic media have a significant impact on the quality of teaching as well as on faculty-student pedagogical relationships. Zhao \& Kuh (2004) described electronic social networks as a very effective tool that allows faculty members to simplify and improve teaching and learning in their classroom settings, especially since students find the experience of electronic interactions both exciting and highly engaging and as an avenue for collaboration with classmates and peers.

The author has systematically worked social media into class assignments over the past three semesters, and business communication course content and objectives have been redesigned and expanded. Electronic media and social networking sites have been integrated to enhance course materials and closely monitor students' efforts and works-in-progress. The entire course sequence and activities are divided into two overlapping phases, consisting of fundamental levels content activity and small-group work. In the first phase, students are taught in a hybrid format that involves face-to-face introductory and foundational lectures, conceptual definitions, coursespecific vocabulary delineation, as well as mastery of presentation format in preparation for the mid-term examination. Subsequently, in phase two of the course work, students are prepared for the final examination and group projects. Various homework assignments consisting of case analyses, team work, library/data base searches, planning, and writing business messages are assigned via the Blackboard and Facebook. In these electronic media assignments, participation and feedback are highly required and 10-15 points are assessed for the quality of participation, which is measured by the number of constructive and consecutive responses and answers, and for timely submission of individual and group projects. Since the integration of this system of teaching in business communication classes, participation and responses via Facebook and Blackboard have accelerated and have also increased students' interest in homework assignments. Discussing the role of social networking technologies, Warren (2010) explained that among the channels in the system. Facebook has been extremely effective in disseminating information to students, colleagues, and friends. It facilitates social and academic communication, interaction in a "trusted environment," and provides a global context and impact. As Table 1 indicates, social 
networking has affected many aspects of the contemporary world, specifically education and business, via the Facebook system. A unique feature of social networking is the capability to facilitate immediate engagement between students and instructors (Mason \& Rennie, 2008). Globalization has tremendous impact on modern societies and through the Internet/Facebook systems, teaching and learning, as well as business activities, have expanded profitably.

Table 1: Social Networking and Teaching

\begin{tabular}{|l|c|c|}
\hline \multicolumn{1}{|c|}{ Region } & Number (millions of users) & \% Regional Penetration \\
\hline Asia & 704.2 & 50.5 \\
Europe & 402.4 & 73.9 \\
North America & 251.7 & 30 \\
Latin America/Caribbean & 175.8 & 6.7 \\
Africa & 65.9 & 23.7 \\
Middle East & 48 & 60.1 \\
Oceania/Australia & 20.8 & $\mathbf{2 4 . 7}$ \\
World Average & & \\
\hline
\end{tabular}

Source: Shona Leitch \& Mathew Warren (2011).

In recent years, it has been noted that the use of social networking has varied among nations and stakeholders. The use has dramatically increased in some nations and continents. As the above table indicates, the number of users in Asia and Europe far exceed users in other places. For example, in Australia and Oceania, the number of users is exceedingly low.

The following two questions guided in the assessment of the role, effectiveness, advantages, and drawbacks associated with social networking and electronic media in teaching and learning business communication: 1) What are the strengths and weaknesses, drawbacks, or challenges of electronic media and social networking in teaching business communication? 2) How can electronic media and social networking improve teaching and learning of the course? Indeed, experiences gained from teaching the course via electronic media have been both challenging and enriching. For one thing, students establish good friendship, build interpersonal relationships, and interact among themselves. Some of the students, especially international students, who were reluctant or uncomfortable participating in class discussions, submitted their assignments to the Blackboard on time and provided good answers. Their constructive feedback and responses to questions were appropriate and reflected an understanding of content and context of reading assignments and projects explained in class. However, a constant challenge in using electronic media and social networking in class is students' increased rate of absenteeism and truancy and the inability to ensure that assignments reflected genuine efforts of students. While a lot of emphasis was placed on working independently, there were students whose homework assignments or projects posted on the Blackboard or Facebook did not adequately indicate individual performance. As a result, students were often required to present selected homework assignments during face-to-face class sessions in order to validate their efforts and distinguish between assignments done independently and collaboratively.

\section{BACKGROUND ON SOCIAL NETWORKING}

Some studies (Mason \& Rennie, Leith \& Warren, 200b, and Warren, 2010) have noted that in recent years, social networking and electronic media have revolutionized the processes of teaching and learning, and created new challenges and opportunities in higher education teaching and learning. Both faculty members and students have shared the pros and cons of this innovative classroom setting that constantly challenges them with sophisticated learning approaches. The widespread impact of the Internet is felt in many parts of the global society, including business, education, and social interactions. Notably, a critical feature of the electronic media and social networking is their capability to establish and encourage engagements and interactions among people, academic institutions, and business organizations. Mason \& Rennie (2008) indicated that in an educational environment, communication between students and faculty members is of paramount importance in ensuring accountability and responsiveness, and that electronic media has been instrumental in achieving these objectives. 
Evidently, technological and media environment of the twenty-first century have largely affected and enhanced business operations and academic activities. The impact appears more pronounced in higher education where the process of teaching and learning has moved to a new dimension. Baird \& Fisher (2006), explaining the advantages associated with social networking in educational planning and design, stressed that in some universities, courses are taught hybrid (face-to-face and web-enhanced) as well as completely online applications, which has provided tremendous learning opportunities to students. In addition, Wandel (2007) noted that a critical technological innovation in the educational system around the world in the twenty-first century is the introduction of online social network sites, electronic media, and public Web sites. These developments promote individual and group interaction, collaboration, and socialization, as well as immediate feedback for quality of learning control and assurance. Baird and Fisher (2006) and Wandel (2007) evaluated the effect of social networking in the teaching environment and determined that sites such as Friendster, MySpace, and Facebook, which are important in college and university levels, enable students to communicate with one another, discuss academic and social matters, and engage in productive group projects.

\section{What are the Strengths of Using Electronic Media and Social Networking in Teaching Business Communication?}

Numerous theoretical and empirical studies spanning over decades on social networking sites and electronic media in higher education strongly indicate that the system has become increasingly significant in eduating present and future students. For example, in a 2007 study by the PEW Internet and American life Project, it was stated that more than half of all online teens use social networking. This national study of youths ages 12-17 reported that 55 percent use social networking sites and 48 percent visit the sites daily or more often. Most respondents (91 percent) indicated that the sites were effective ways to connect and stay in touch with friends they see face-to-face. Although social networking sites have been criticized for allowing hormones to flair with racy photographs, sexy dialogue, and incriminating evidence of alcohol consumption and illegal drug use (Shropshire, 2006, and Young, 2006), faculty members, administrators, and staff are constantly using these sites to reach or communicate with their students, mentees, and advisees (Wandel, 2007). Recent scholarly works have explained that the Internet/social media has the potential to make teaching and learning more effective and productive. Santovec (2006) described electronic media as a critical strategy for engaging students in classes, citing Florida's Rollins College, Pennsylvania's Mansfield University, and the University of Alabama, as taking advantage of social networking sites in communicating with students about academic matters. The author further noted that faculty members at Capital University in Columbus, Ohio, established a social networking site for students interested in planning and developing an internship experience. Arieanna (2007) highlighted social networking educational benefits and cited a survey commissioned by the National School Boards Association (NSBA) which demonstrated that $50 \%$ of the students talk online with classmates about school (IM, blog or social networking sites) or via text message, a large proportion (60\%) of students state that they discuss education-related topics, such as college and career planning, and $96 \%$ of them indicate that access to networking sites is helpful in cultivating and expanding friendship networks. The study then concludes that social networking and communication media provide students the flexibility to learn anytime and anywhere, study at a convenient pace and time, have the opportunity to brainstorm with classmates, and devote more time to assignments.

Stressing that students world-wide value the advent of social networking sites and the use of electronic media as a conduit, Thompson (2007) surveyed students who reported preferences for the application of information technology by faculty members, which is consistent with other studies (Selwyn, 2009, and Madge, Wellens \& Hooley, 2009) that sustainability of the interest in learning for Generation M would involve the integration of information technology into pedagogical practices and strategies. The authors noted that students at various universities exchange information regarding reading assignments, course selections, preparation for tests and examinations, and missed assignments. Fundamentally, the social network sites have expanded students' support system, increased their interest in team work, and enhanced dependability on one another. 


\section{What Are the Weaknesses/Challenges of Using Electronic Media and Social Networking in Teaching Business Communication?}

Past studies demonstrate divergent views on the effectiveness of social networking in preparing students for acquiring essential communication skills for the workplace. For example, Lea (1992) and Sproull \& Kiesler (1986) indicate that electronic media and social networking or computer-mediated communication create inadequate or substandard educational exchange because of the impersonal structure associated with teaching via technological tools. Nie (2001) shares concern that extensive use of the Internet or electronic media in teaching minimizes the critical role of face-to-face interactions with students in class sessions. Faculty members' ability to monitor or supervise social network activities is tasking and time-consuming, and it grossly affects content mastery and intellectual performance. Additional drawbacks of electronic social networks include students' low and inconsistent online participation, poor attendance, and inability to understand and comply with instructions for completing assignments. Zhao \& Kuh (2004) summarized students' apprehension about safety, privacy, and ethic standards while in online environment.

\section{How Can Electronic Media and Social Networking Improve Teaching and Learning of the Course?}

Electronic media and social networks can improve teaching and learning by monitoring or tracking the activities of both students and faculty members, and the quality and quantity of students' engagement and class participation can be measured by using an electronic marking and feedback device (Bambina, 2007). To achieve a maximum level of participation and interaction, faculty members should organize students in small groups, assign points for relevant comments and discussion online, and should provide immediate feedback online in order to hold students accountable. Additionally, Wellman, Witte, \& Hampton (2001) cautioned that the electronic media should be used in a form that does not intimidate students or make them uncomfortable about learning assigned materials. When students are comfortable or relaxed, they will be capable of writing appropriate answers and responses to questions, and this is particularly important for those students who find face-to-face interactions exceedingly difficult.

\section{CONCLUSION}

For maximum productivity, it is important to use communication technologies to augment and compliment rich, face-to-face communication and for the development of excellent interpersonal communication skills. As Cardon \& Okoro (2011) indicated, technological tools (electronic media) should not be used to substitute for interpersonal communication. Rather, they should be used to complement face-to-face lectures and discussions. Extensive use of electronic media in teaching will affect interpersonal skills development. Indeed, students will not be adequately prepared for the workplace where interpersonal skills and oral presentation are critically important. The demand for strong interpersonal communication skills is as important as ever. For example, in presenting with PowerPoint, students should not use it as "a crutch in their presentations." In other words, students should use PowerPoint to supplement the presentation, but not depend largely on it. As useful as electronic media and social networking tools have been, students should be reminded that they are the focus in a communication context. Therefore, faculty use of the electronic media should be strategically integrated to enhance the acquisition of fundamental communication skills and competencies.

\section{AUTHOR INFORMATION}

Ephraim A. Okoro, $\mathrm{PhD}$ is an assistant professor of business communication and marketing at Howard University. His research interests probe the interface between intercultural communication and workforce diversity in the context of globalization. He teaches business communication, marketing communication, management communication, and principles of marketing. Address correspondence to Dr. Ephraim Okoro, Department of Marketing, School of Business, Howard University, 2600 - Sixth Street, NW, Washington, D.C. 20059; E-mail: eaokoro@ howard.edu. (202) 806-1545 


\section{REFERENCES}

1. Arieanna (2007, August 21). Educational benefits of social networking. Education week.

2. Baird, E.E., \& Fisher, M. (2006). Neomillenial user experience design strategies: Utilizing social networking media to support "always on" learning styles. Journal of educational technology systems, 34(1), 5-32.

3. Bambina, A (2007). Online social support: The interplay of social networks and computer-mediated communication. Amhertst, NY: Cambria Press.

4. Okoro, E., Cardon, P., \& Washington, M. (2011, September). "E-Portfolios in business communication courses as tools for employment." Business Communication Quarterly.

5. Cohen, E.G. (1994). Structuring the classroom: Conditions for productive small groups. Review of Educational Research, 64(1), 1-35.

6. Genova, G. L. (2009, March). No place to play: Current employee privay rights in SNS. Business Communication Quarterly (97-101).

7. Hakanen, J., Bakker, A., Scaufeli, W. (2006). Burnout and work engagement among teachers. Journal of School Psychology, 43(6), 495-513

8. Hathi, S. (2008, February/March). Billions lost from social networking. Strategic Communication

9. Lea, M. (ed.). (1992). Contexts of computer-mediated communication. Harvester-Wheatsheaf, New York.

10. Leith, S., Warren, M. (2008b). Analyzing online teaching and learning systems using MEAD. Interdisciplinary Journal of E-Learning and Learning Objects, 4, 259-267. Retrieved from Http://.ijello.org/volume 4/IJELLOv4p259-267Leitch497.pdf

11. Madge, C. Meek, J., \& Hooley, T. (2009, June). Facebook, social integration, and informal learning at University: It is more for socializing and talking to friends about work than for actually doing work. Learning, Media and Technology, Volume 34, Number 2 (141-155).

12. Mason, R., \& Rennie, F. (2008). Learning and social networking handbook: Resources for higher education. USA: Routledge.

13. Nie, H.H. (2001). Sociability, interpersonal relations, and the Internet: Reconciling conflicting findings. American Behavioral Scientist, 45 (3), 420-435.

14. Santovec, M.L. (2006, March). Using online networking to engage and retain students. Recruitment and retention in higher education, 20 (3), 1, 3, 7 5. Academic Search Premiere.

15. Selwyn, N. (2009, June). Faceworking: Exploring students' education-related use of Facebook. Learning Media and Technology, Volume 34, No2, (157-174)

16. Shropshire, C. (2006, September 29). Facebook faces uncertainty. Pittsburgh post gazette. www.postgzeette.com/pg/06272/725984-96.stm

17. Sproull, L., Kiesler, S. (1986). Reducing social context cues: Electronic mail in organizational computing. Management sciences, 32 (11), 1492-1512

18. Suskie, L. (2004). Assessing student learning: A common sense guide. Boston, MA. Anker.

19. Wandel, T. (2007, July). About Facebook: Educational institution responses to online social networking. WCA Conference, Brisbane.

20. Warren, M. (2010). Security risks of social networking systems (Keynote Presentation), $4^{\text {th }}$ IEE International Conference on Network and Systems Security, Melbourne, Australia.

21. Leitch, S. \& Warren, M.J. (2011). Social networking and teaching: An Australian case study. Proceedings of Informing Science and IT Education Conference, Victoria, Australia.

22. Young, J. (2002, February 21). Creating online portfolios can help students see 'Big Picture,' colleges say. Chronicle of Higher Education, http://chronicle.com/ free/200202210t.htm.

23. Young, J.R. (2006, August 4). Facebook and other social networking sites raise questions for administrators. Chronicle of higher education, 52 (48), Academic Search Premiere.

24. Zhao, C. \& Kuh, G. (2004). Adding value: Learning communities and student engagement, Research in Higher Education, 45 (2), 115-138. 